\title{
The effects of economic anxiety on affective occupational commitment: The mediating role of emotional exhaustion
}

\section{Ekonomik kaygının duygusal mesleki bağlılık üzerindeki etkileri: Duygusal tükenmişliğin aracılık rolü}

\author{
Serap Benligiray ${ }^{1}$ \\ Duygu Yetgin ${ }^{2}$
}

1 Prof. Dr., Anadolu Univesity, Faculty of Economics and Administrative Sciences, Eskişehir, Turkey,

sbenligi@anadolu.edu.tr

ORCID: 0000-0003-1004-8318

2 Asisst. Prof., Anadolu University, Faculty of Tourism, Eskişehir, Turkey,

dyetgin@anadolu.edu.tr

ORCID: 0000-0002-9909-4523

\section{Corresponding Author:}

Duygu Yetgin,

Anadolu University, Faculty of Tourism Eskişehir, Turkey,

dyetgin@anadolu.edu.tr

Submitted: 9/05/2021

Revised: 19/06/2021

Accepted: 15/07/ 2021

Online Published: 25/09/2021

Citation: Benligiray, S., \& Yetgin, D., The effects of economic anxiety on affective occupational commitment: The mediating role of emotional exhaustion, bmij (2021) 9 (3): 869-889, doi:

https://doi.org/10.15295/bmij.v9i3.1838

\begin{abstract}
This study aims to examine whether emotional exhaustion has a mediating role in the effect of economic anxiety of tour guides on their affective occupational commitment. The research sample included 370 tour guides in Turkey. The data were collected through the questionnaire method. The collected data were analyzed using the IBM SPSS 22 and Process v3.3 macro extension. The mediating role of emotional exhaustion between economic anxiety and affective occupational commitment was calculated via the Bootstrapping procedure. It was found that there was a weak negative relationship between economic anxiety and affective occupational commitment, a positive relationship between economic anxiety and emotional exhaustion, and a negative relationship between affective occupational commitment and emotional exhaustion. Thus, emotional exhaustion reduces affective occupational commitment levels, and emotional exhaustion has a partial mediating role between economic anxiety and affective occupational commitment. This study is expected to raise awareness in tour guides, attract those who employ tour guides, and contribute to the relevant literature.
\end{abstract}

Keywords: Tour Guiding, Economic Anxiety, Affective Occupational Commitment, Emotional Exhaustion, Turkey

Jel Codes: J53, L83, L84

Öz

$\mathrm{Bu}$ çalışmanın amacı, Türkiye'deki turist rehberlerinin ekonomik kaygılarının, onların duygusal mesleki bağlllıkları üzerindeki etkisi üzerinde duygusal tükenmişlik durumunun aracı rolünün olup olmadığını incelemektir. Araştırmanın örnekleminde Türkiye'de faaliyet gösteren 370 turist rehberi yer almıştır. Veriler anket yöntemiyle toplanmıştır. Toplanan veriler IBM SPSS 22 ve Process v3.3 macro extension kullanılarak analiz edilmiştir. Ekonomik kaygı ve duygusal mesleki bağlılık arasında duygusal tükenmişliğin aracı rolü bootstrappingyöntemi kullanılarak hesaplanmıștır. Analizler sonucunda ekonomik kaygı ile duygusal mesleki bağlılık arasında zayıf negatif ilişki, ekonomik kaygı ve duygusal tükenmişlik arasında pozitif ilişki ve duygusal mesleki bağlllık ve duygusal tükenmişlik arasında ise negatif ilişki saptanmıştır. Duygusal tükenmişliğin duygusal mesleki bağlılık düzeylerini azalttığı ve ekonomik kaygı ve duygusal mesleki bağlılık arasında kısmi bir aracı role sahip olduğu görülmüştür. $\mathrm{Bu}$ çalışmanın tur rehberlerini bilinçlendirmesi, tur rehberlerinin işverenlerinin dikkatini bu yöne çekmesi ve ilgili alanyazına katkıda bulunması beklenmektedir.

Anahtar kelimeler: Turist Rehberliği, Ekonomik Kayg1, Duygusal Mesleki Bağllık, Duygusal Tükenmişlik, Türkiye

JEL Kodları: J53, L83, L84 


\section{Introduction}

Tour guiding is a profession with its characteristics, qualifications and standards. As in every profession, this profession has various positive and negative aspects. This stems from various positive and negative features of the tour guiding business. The occupation of tour guiding attracts many people because it is an entertaining, innovative, and non-monotonic job that offers professional autonomy, brings out social skills, offers freedom of travel, and allows people to witness their customers' most enjoyable and happiest moments (Wong and Wang, 2009; Mancini, 2001). However, it should also be noted that it is a job that requires tour guiding professionals to be enthusiastic and knowledgeable people with good management skills, who should also display customer-oriented and ethical behaviours (Ap and Wong, 2001). It should also be noted that this is a physically and mentally exhausting job that requires working under any climatic conditions; indoors or outdoors, travelling very frequently and working long and flexible hours; usually working seasonally in peak seasons and various destinations; continuous occupational and self-improvement and undertaking essential responsibilities (Weiler and Black, 2015). Such difficulties that derange work-life balance cannot be overcome by individuals who do not love what they do for a living, and who fail to embrace their professional values, who do not identify themselves with their jobs and to accept their jobs as a part of their lifestyles (Meged, 2017). The most crucial type of commitment for tour guides is affective commitment. In other words, tour guiding is an occupation that may not be practised without maintaining some affective commitment.

Economic anxiety is a kind of anxiety that individuals experience in financial insecurity (Osberg, 2009). Many problems are arising from the work and conditions of tour guides, such as lack of wage continuity due to precarious employment conditions and seasonal employment (mainly when they are not working for a travel agency and work freelance); the lack of retirement rights of guides; the high competition among the guides and the unfair competition created by the illegal (unlicensed or unauthorized) guides, can cause them to experience economic anxiety. (Yetgin, 2017; Yetkin and Benligiray, 2019). Macroeconomic conditions are also the threatening contextual elements that affect how individuals review their lifestyles and work conditions (Bell and Blanchflower, 2011). Factors such as national or global crisis, economic recession, national and international political events, natural disasters, terrorism, and epidemics often significantly affect the tourism industry (Lerhman, 1986). Since these macroeconomic problems can threaten tourists' safety (life and property), they are considered significant determinants of tourist demand. These problems have the potential to eventually reduce the demand for tour guides and lead to unemployment. In this case, it will be inevitable for unemployed tour guides to suffer from economic difficulties and anxiety about future economic conditions.

Emotional exhaustion is the state of emotionally worn-out and drained and lack of emotional resources (Maslach and Goldberg, 1998). Emotional Exhaustion is accepted as the beginning of the burnout syndrome, and it is also the state where the exhaustion can be most explicitly observed and easily analysed (Maslach and Jackson, 1981). The people experiencing emotional exhaustion fail to act responsibly to their superiors as they used to; they do not value their jobs as before and feel a rapid decrease in their emotional and physical resources. Being forced to go back to work under extreme stress and frustration becomes a significant source of anxiety and stress (Leiter and Maslach, 1988: 297). The economic anxieties experienced by tour guides may also increase their levels of emotional exhaustion. In addition to their economic anxieties, tour guides may also go through some disturbing, unnerving, and upsetting experiences resulting from their roles as tour leaders. These hassles may stem from leading a tour, tour agent and their difficulties in their personal lives. The difficulties they have during a tour may include annoying behaviours of participants and other employees, disagreements between tour guides and groups, and having to take responsibility because of the problems caused by others. The difficulties caused by travel agencies include the unfulfilled tasks by the personnel of the tour agency, characteristics of the tour, inconsistencies between styles of tour leaders, and excessive regulations of travel agencies. The difficulties they have in their personal lives are conflicts between work and family life, occupational illnesses, insufficient and irregular income, difficulties in forming and retaining social relations and poor management of leisure time (Tsaur and Lin, 2014). Excessive workload and more extended periods of fast-paced work hours bring emotional exhaustion (Wright and Bonett, 1997). These difficulties can lead to exhaustion in tour guides (Visser and Rothmann, 2009) and prevent them from maintaining their jobs (Abdelkader, 2016).

The occupational groups that require face-to-face communication and close relationships can experience burnout syndrome more frequently (Maslach and Jackson, 1981). As service providers, tour guides are frequently in face-to-face communication with their customers. Tour guides are always expected to be kind, respectful, easy-going, and polite to their customers. However, customers do not necessarily have 
to treat them kindly. They can even be irreconcilable, rude, and hostile (Chu and Murrmann, 2006; Rafaeli, Grandey, Ravid and Wirt,z 2006). Tour guides have to hide and suppress their true feelings may cause them to get stressed (Toker, 2019; Adams and Webster, 2013; Swim, Johnston and Pearson, 2009; Goldberg and Grandey, 2007), and may lead to decreased job satisfaction, increased fatigue and workplace mistreatment among colleagues and absenteeism (Walker, van Jaarsveld and Skarlicki, 2014), emotional exhaustion, all of which eventually cause them to quit their jobs (Chang, Chi and Miao, 2007; Visser and Rothmann, 2009).

The purpose of this study is to test whether emotional exhaustion has a mediatory effect on the relationship between economic anxiety and affective occupational commitment of a group of tour guides. The research sample included 370 active tour guides in Turkey. The data were collected through the questionnaire method. The mediating role of emotional exhaustion between economic anxiety and affective occupational commitment was calculated via the Bootstrapping procedure. This study found a weak negative relationship between economic anxiety and affective occupational commitment, a positive relationship between economic anxiety and emotional exhaustion, and a negative relationship between affective occupation and affective occupational commitment. It was also revealed that emotional exhaustion had an intermediary role between economic anxiety and affective occupational commitment. This study is expected to raise awareness in tour guides, attract the attention of those who employ tour guides, and fill an essential gap in the related literatüre

\section{Literature review, hypotheses development and research framework}

\section{Affective occupational commitment}

Occupation means working at a specific job for a period for one's survival and the satisfaction of one's biological, social, and psychological needs (Lee, Carswell and Allen, 2000). A person's occupation is related to his/her choices, preferences, and interests. When a person becomes a member of an occupational group, s/he also becomes familiar with the values and viewpoint regarding the chosen occupation and develops a sense of identity (Rothman, 1997). Thus, occupation may also be defined as a social value practised by individuals with common cultural characteristics, viewpoints, lifestyles, values, principles (Maldonado and Alicea, 2002).

For professionals to succeed in any career path, they should develop a deep commitment to their occupations (Benligiray and Sönmez, 2013). The commitment may be defined as a desire to maintain a valued relationship for a long time or a force that pushes an individual towards behaving for a particular purpose (Meyer and Herscovitch 2001). Accordingly, occupational commitment is the connection individuals develop with their occupations based on their emotional reactions regarding their desire to maintain their occupation and work for a specific purpose (Lee et al., 2000).

The occupational commitment was studied one-dimensionally (Aranya and Ferris 1984; Greenhaus, 1971; Ritzer and Trice 1969), multi-dimensionally (Meyer, Allen ve Smith, 1993), three-dimensionally (Blau 2003), and four dimensionally in the literature. The dimensions of occupational commitment formulated by Meyer et al. (1993) are practical, continuance, and normative occupational commitment. Blau (2003) based his work on sub-dimensions of occupational commitment; however, he suggested that continuance commitment has two different sub-dimensions as accumulated costs and limited alternatives. Consequently, Blau (2003) examined occupational commitment in four dimensions as affective, normative, accumulated costs and limited alternatives. Affective occupational commitment is the most significant type of commitment in terms of employees' occupational identification, dedication to their occupations, and values. Affective occupational commitment is defined as perceiving one's job as the centre of his life and making an effort to improve his occupational skills (Meyer and Allen, 1997). Affective occupational commitment occurs when employees work willingly with positive vibes, adopt and embrace occupational values, and identify with their jobs (Blau 2003, Meyer et al. 1993). Since this type of commitment reflects individuals' desires to continue their occupations, it represents a more vital type of commitment when compared to other sub-dimensions (Kim and Chang, 2007; Meyer and Herscovitch, 2001). It is seen that affectively committed individuals make more efforts to become better at what they do, attach more importance to their professional development, follow all occupational publications for this purpose, attend work-related conferences and follow scientific studies that would improve their professional expertise (Lee et al., 2000; Meyer et al., 1993).

\section{Economic anxiety}

Anxiety is one of the concepts defined in the psychology and philosophy literature and has been defined and explained by various scientists and philosophers. This concept is defined in psychology as a state of discomfort or depression, and in addition to its meaning in psychology, it is also defined as a 
determining and vital force in the way of existence (Ditfurth, 1991). Anxiety entered the psychology literature with Freud's concept of neurotic anxiety. Freud (1984) argued that the anxiety experienced by ordinary people differs from neurotic anxiety in terms of its characteristics. Freud described this type of anxiety commonly experienced by ordinary people as "real anxiety" and suggested it was more like fear. Realistic anxiety is reasonable and understandable as it is a manifestation of survival and protection instincts. In contrast, neurotic anxiety has no cause or object; it is irrational, continuous, and pathological (Geçtan, 2005).

Everyone gets nervous from time to time. This is a natural and common human response to many life challenges (Weiten, Hammer and Dunn, 2016). However, when the individual perceives his future as more uncertain (Kierkegaard, 2004), the situation becomes even more frightening for him. In this case, the individual may not be able to control the anxiety he feels, and he may become unable to cope with this feeling with his existing capacity, which may cause the level of anxiety to increase gradually (Dağ, 1999) and may enter a vicious circle in which anxiety disorder emerges. People with higher levels of anxiety sensitivity tend to react more strongly to specific symptoms with fear (Weiten et al., 2016).

According to Friedman and Schustack (1999), anxiety is intense fear or uncertainty and a situation affected by internal or external factors resulting from a threat or expectation of challenge. One of the most important external factors that cause people to feel anxiety is economic conditions. Deterioration of financial security and stability is mainly associated with the growing senses of fear, ambiguity, and concern over whether the individual will sustain their standard of living (Marjanovic, Greenglass, Fiksenbaum and Bell, 2013). Certain economic conditions can lead to economic insecurity and economic anxiety. These conditions include economic crises (economic recession and global financial crises) (Osberg 2015), rising unemployment rates (Osberg 2015; Luechinger Meier and Stutzer, 2010; Whalen 1997; Lozza, Libreri and Bosio, 2012), declining job security (Osberg and Sharpe 2005, László, Pikhart, Kopp, Bobak, Pajak, Malyutin and Marmot, 2010), a high number of dependents, indebtedness, family pressure (due to higher expectations, desire to maintain living conditions and social level, negative attitudes) (Larson, Wilson and Beley, 1994), new and lack of an alternative occupation (Whalen, 1997), deteriorating health status (Rook, Dooley and Catalano, 1991).

Economic anxiety and economic hardship must be carefully distinguished. Hardship refers to the economic struggles of a person, such as poverty, unemployment, decreasing wages, confiscation, bankruptcy. On the other hand, anxiety is not about economic hardships; it is about anxiety about one's future economic condition due to the conditions mentioned above (Finbow 2018; Casselman 2017). In other words, economic anxiety is the fear individuals experience at the micro-level due to adverse economic conditions. According to Osberg (2009), economic anxiety is an anxiety that individuals experience in financial insecurity. Marketplace and Edison Research has developed an instrument to help define how the economy makes its presence felt personal. "The Economic Anxiety Index", published on October 26, 2015, classified the results in three broad categories: (1) General Anxiety: It is related to general concerns of people about money. It is about how strong and secure people feel financial, how often they feel anxious about their financial conditions, and whether they lose their sleep due to their financial matters. (2) Savings and expenses: It is related to people's fears about monthly household costs and expenses, travel expenses, student loans, and unexpected medical bills. (3) Job security: It is related to the fear of unemployment and how secure they would feel regarding meeting their expectations and needs in case of unemployment.

Economic anxiety's most significant potential outcome is a mental disorder (Osberg 2009; Meltzer, Bebbington, Brugha, Jenkins, McManus and Stansfeld, 2009). Other potential outcomes of economic anxiety are lack of self-confidence, fear of lower living standards and marital conflict (Osberg, 2009; Meltzer et al., 2009), miscommunication and anxiety in people's social circles, a predisposition towards leaving their job (Lozza, Libreri and Bosio, 2012), decreased job satisfaction and motivation (Whalen, 1997), and decreased productivity (Osberg, 2009).

\section{The relationship between economic anxiety and affective occupational commitment}

Besides the effects mentioned above, economic anxiety may also cause tour guides to lose their organizational or occupational commitments (Markovits, Boer and Dick, 2014). However, tour guides with higher affective occupational commitment levels are expected to have lower economic anxiety levels. Therefore, economic anxiety is not expected to affect affective occupational commitments significantly. In other words, economic anxiety will have little or no effect on tour guides' affective occupational commitment. The reason for this could be better understood after the causes and consequences of affective occupational commitment are analysed. 
The literature review revealed that researchers found different results regarding the relationship between affective occupational commitment and demographic features, such as age, gender, marital status, educational background, seniority. Therefore, it is not easy to claim that a person from a specific demographic will develop more affective occupational commitment than others. However, it could be concluded that affective occupational commitment starts when an individual chooses an occupation and takes shape with their occupational experiences (Meyer et al. 1993; Lee et al. 2000). It is found that individuals have lower affective occupational commitment levels at the onset of their careers, and as they continue to gain more occupational experience (Tang, Cunningham, Frauman, Ivy and Perry, 2012; Goulet and Singh 2002; Lee, Carswell and Allen, 2000) and success, and as they become more familiar with their occupations, their affective occupational commitment levels increase. As individuals use their knowledge, skills, and competencies in their jobs, they receive various (tangible and intangible) rewards and achieve their career goals, and their affective commitment levels increase (Weng and McElroy, 2012). Their adequate occupational commitment levels increase with their positive experiences, opportunities, and satisfaction (Tak and Çiftcioglu, 2009).

Employees with a high level of emotional commitment to their occupation develop more positive feelings towards their occupation (Cunningham, Tang, Frauman, Ivy and Perry, 2012; Blau 2003; Meyer et al., 1993); they identify more strongly with various beliefs and values related to their occupation (Lee et al. 2000), they see themselves as a part of the occupation (Bagraim, 2003), and therefore they never think of changing their occupation (Weng and McElroy 2012; Otto, Dette-Hagenmeyer and Dalbert, 2010; Chang et al., 2007; Meyer and Herscovitch 2001; Blau 2000; Meyer et al. 1993; Blau, 1989).

Employees with high affective professional commitment tend to adhere more carefully to professional standards and ethical principles (Lee et al. 2000; Jeffrey, Weatherholt and Lo, 1996), share tacit knowledge (Lin, 2007), take more personal responsibility from others (Kaplan and Whitecotton, 2001), display more organizational citizenship and voluntary behaviour (Meyer et al., 1993), improve their performance (Conner, 2005; May, Korczynski and Frenkel, 2002; Lee et al., 2000), become more participatory (May et al., 2002; Lee et al., 2000), and less absenteeism (Özer and Uyar, 2010).

People with high-level affective occupational commitment also have higher job satisfaction (Satoh, Watanabe and Asakura 2017; Kaldenberg, Becker and Zvonkovic, 1995; Meyer et al., 1993), organizational commitment (Blau, 2000; Cohen, 2007; Lee et al., 2000), productivity, motivation (Güleryüz, Güney, Aydın and Aşan, 2008), and life satisfaction levels than the others. Research shows that occupational commitment and exhaustion have a strong relationship, but they hurt each other. People with high-level affective occupational commitment have lower levels of work stress (Pai, Yeh and Huang, 2012) and burnout (Knudsen, Roman and Abraham, 2013; Brown and Roloff, 2011; Raiziene and Endriulaitiene, 2007). Thus, the following hypothesis was developed:

\section{$\boldsymbol{H}_{1:}$ Economic anxiety negatively affects affective occupational commitment.}

\section{Emotional exhaustion}

Burnout (Job burnout or staff burnout) is a state of exhaustion resulting from unmet demands or work and energy loss due to failure, fatigue, or excessive workload. According to Maslach, burnout occurs when employees feel emotionally exhausted, become desensitized towards the people they meet as part of their jobs, and when they feel like their personal accomplishments and competencies are not sufficient (Maslach, 2003) as a result of exposure to chronic work stress for extended periods (Maslach, Schaufeli and Leiter, 2001).

Burnout syndrome, a stress-related psychological disorder that arises over very long periods, has been the topic of discussion for many scholars, and many models have been suggested for conceptualization. These models are the burnout models developed by Maslach and Jackson (1981) and Meier (1983). Maslach's Burnout Inventory is the most common model in the literature, and various researchers have tested its validity and reliability. In Maslach's Burnout Inventory, burnout was analysed in three dimensions: emotional exhaustion, depersonalization, and personal accomplishment. While these three dimensions appear to be different, they are closely related to each other.

Emotional exhaustion is the state of emotionally worn-out and drained and lack of emotional resources (Maslach and Goldberg, 1998). Emotional exhaustion (fatigue, exhaustion) is an easily observable and inspectable dimension, and it is accepted as the beginning and the most critical phase of the burnout process. Since this is the initial symptom, it generally plays a significant role in both burnout experience and its treatment (Maslach and Leiter, 1997). The factors that cause emotional exhaustion include stress (Maslach and Jackson, 1981), work overload (Griffin, Fuhrer, Stansfeld and Marmot, 2002; Lee and Ashforth, 1996), mobbing (Davenport, Schwartz and Elliott, 2003), confrontation with a false notion 
regarding one's occupation (Fawzy, Fawzy and Pasnau, 1991), lack of control at work, role conflict (Leiter and Maslach, 2003), insufficient rewarding-wage, prestige, security (Maslach and Leiter, 1997), unfair organizational structure/negative justice perception (Maslach, Schaufeli and Leiter, 2001), overemotional expectations, the need for suppressing or expressing emotions routinely and chronic use of empathy (Maslach et al., 2001). However, studies show no significant relationship between demographic variables and emotional exhaustion (Maslach and Jackson, 1981).

Emotional exhaustion of employees harms both employees and their organizations. Emotional exhaustion of employees significantly reduces their job performance (McCarthy, Trougakos and Cheng, 2016; Kim, Yoo, Lee and Kim, 2012; Lingard and Francis, 2005), their capacity to take the initiative and cope with challenging tasks (Lingard and Francis, 2005), their life satisfaction (Burke and Greenglass, 1996), passion for work, emotional labour strategies, positive attitudes towards their profession, interest and confidence, job satisfaction (Garman, Corrigan and Morris, 2002), and organizational commitment (Jackson, Turner and Brief, 1987). On the other hand, emotional exhaustion causes an increase in absenteeism (Deery, Iverson and Walsh, 2002), intention to leave (Han, Bonn and Cho, 2016; Maslach and Jackson, 1997), and anxiety levels (Maslach and Leiter, 1999) of employees.

\section{The relationship between economic anxiety and emotional exhaustion}

No studies could be found in the literature concerning the correlation between economic anxiety and exhaustion. However, studies indicate that variables such as low-income levels and insufficient wages lead to exhaustion (Anastasiou, 2020). In addition, when individuals do not believe that they are being rewarded fairly for their efforts, they experience exhaustion. As a result, individuals begin to work at a side job, increasing their emotional exhaustion level by increasing their workload (Maslach and Leiter, 1997).

Çağan's (2014) study on nurses and Otacioğlu's (2008) study on music teachers reveal that the individuals who believe that their financial conditions are weak tend to have higher levels of emotional exhaustion. In a study investigating the relationship between employees' economic perceptions and their emotional exhaustion, it was found that teachers who were not satisfied with their wages experienced higher levels of emotional exhaustion (Çelebi, 2013). In another study, it was found that as the anxiety levels of health workers increased, their emotional exhaustion levels also increased. Because when individuals cannot cope with stress effectively, they begin to exhaust themselves emotionally (Cotton, 1990). It is also understood that when individuals cannot cope with stress, they are more likely to experience emotional exhaustion, even under the same level of work stress (Verbeke, 1996). Thus, the second hypothesis was developed as follows:

$\boldsymbol{H}_{2:}$ Economic anxiety positively affects emotional exhaustion.

\section{The relationship between emotional exhaustion and affective occupational commitment}

According to Pines (1996), burnout is only evident in highly motivated, idealistic individuals. These individuals are more likely to have higher expectations regarding their careers, and they are more likely to go through emotions, such as stress, alienation, anxiety, and depression, as the duration and intensity of emotional pressure increase. It is observed that employees begin to feel overloaded with work, and they run out of emotional resources in the emotional exhaustion phase. Then these individuals stop acting as responsible with their superiors as they used to, do not value their jobs, and experience a decrease in their emotional and physical resources. At this point, being obliged to go back to work becomes a significant source of anxiety and stress for individuals who experience stress and frustration (Leiter and Maslach, 1988).

A study conducted to test the relationship between teachers' exhaustion and professional commitment levels found a significantly negative relationship between affective occupational commitment and emotional exhaustion levels (Tümkaya and Ustu, 2016). In a different study examining the effects of exhaustion and commitment on professional commitment, it was observed that the level of organizational commitment increases in all dimensions if the emotional exhaustion levels of bank personnel decrease (Firat, 2015). In another study conducted to find out how much the emotional exhaustion levels of nurses affect their professional commitment levels, it was observed that emotional exhaustion levels increased and their professional commitment levels decreased as the rules of emotion and behaviour expected from the employees increased. Their intensity increased (Agirman and Naktiyok, 2014).

In another study examining the relationship between teachers' extra-role behaviour and their exhaustion and professional commitment levels, it was observed that the time spent for extra-role behaviours is positively correlated with levels of exhaustion in teachers, and their professional 
commitment levels decreased compared to others (Brown and Roloff, 2011). Another study conducted with accountants found that those who developed an affective commitment to their profession had lower levels of emotional exhaustion (Çiftioğlu, 2011). The effects of professional commitment levels on emotional exhaustion levels were examined in a study in Lithuania conducted with nurses. The results of this study showed that emotional exhaustion decreased as the levels of empathy and professional commitment increased (Raiziene and Endriulaitiene, 2007). Another study revealed that affective occupational commitment negatively affected emotional exhaustion (Engelberg-Moston, Stipis, Kippin, Spillman and Burbidge, 2009).

In a similar study examining the effect of Chinese medical doctors' level of professional commitment on exhaustion, it appeared that occupational commitment had a maximum effect on exhaustion, and strengthening occupational commitment was an effective way to reduce exhaustion (Liu, Li, Long and Zhan, 2009). It was concluded with the study conducted on nurses that all dimensions of professional and organizational commitment had a maximum effect on the concepts of exhaustion. Another study determined that exhaustion levels of banking personnel harmed professional commitment (Tsai, 2007). Another study also showed that nurses with high occupational commitment had more strongly associated with adverse events and exhaustion (Sawhney et al., 2020). According to the relevant literature, it can be said that there is a strong and negative relationship between professional commitment and emotional exhaustion, emotional exhaustion negatively affects professional commitment, and low occupational commitment also increases exhaustion. Therefore, the third hypothesis is developed as follows:

\section{$\boldsymbol{H}_{3:}$ Emotional exhaustion negatively affects affective occupational commitment.}

The mediating role of emotional exhaustion on the relationship between economic anxiety and affective occupational commitment

As mentioned above, no supportive evidence was found in the relevant literature concerning the relationship between economic anxiety and affective occupational commitment. However, there is evidence claiming that economic anxiety increases emotional exhaustion (Maslach and Leiter 1997; Verbeke 1996; Cotton, 1990) and emotional exhaustion decreases affective occupational commitment (Brown and Roloff, 2011; Engelberg-Moston et al., 2009; Liu et al., 2009; Raiziene and Endriulaitiene 2007; Tsai, 2007). Based on this evidence, the third hypothesis of the research was developed as follows:

$\mathrm{H}_{4}$ : Emotional exhaustion has a mediating role in the effect of economic anxiety on affective occupational commitment

\section{Methodology}

\section{Survey instrument}

This research was designed with an ontological objective and epistemologically positivist approach. In this context, the principal research methodology was designed as a survey study. Accordingly, a questionnaire method was used to collect data in the study. The questionnaire consists of two sections. The first section contains items about the demographic characteristics of the participants. The second section contains items about economic anxiety, affective occupational commitment, and emotional exhaustion.

The "Occupational Anxiety Scale for Prospective Teachers", progressed by Cabi and Yalçınalp (2013), is an eight-factor structure that contains 45 items. The economic anxiety scale (Turkish scale) consists of seven items (e.g. "Fear of failing to satisfy the needs of my family with my income"). The statements in this dimension were measured on a 5-point Likert scale ranging from 1 (strongly disagree) to 5 (strongly agree). Cronbach Alpha value for the economic anxiety scale was found to be 0.88 .

In order to evaluate the adequate occupational commitment levels of tour guides, the statements under the affective occupational commitment dimension of the three-dimensional occupational commitment scale of Meyer, Allen, and Smith (1993) were used in the study. This scale was chosen because it was used by another study conducted on tour guides in Turkey (Arslanturk, 2016), and it is a globally recognized scale that has been used in various occupational fields. The practical occupational commitment scale consists of six items (e.g. "Tour guiding profession is important for my image"). Cronbach Alpha value for affective occupational commitment was found to be 79 .

In order to measure the emotional exhaustion levels of participants, the statements in the emotional exhaustion dimension of the three-dimensional "Maslach Burnout Inventory" were used. The scale was adapted into Turkish (Çapri, 2006) and optimised for tour guides without causing any changes in meaning. Accordingly, "emotional exhaustion" consists of 8 items. (e.g. I feel like I do not like my job 
anymore and feel emotionally drained when I return home from work). Cronbach Alpha value for emotional exhaustion was found to be 0.90 .

\section{Data collection}

The sample consists of tourist guides who are actives. In order to work as a tour guide in Turkey, tour guides must receive a license from the Republic of Turkey Ministry of Culture and Tourism. When this research was conducted in 2016, according to data given by the Turkish Union of Tourist Guides' Chambers, there were 7290 active tour guides in Turkey. A stratified proportional sampling method was used to form a precise sample representing the entire population. While applying this method, the population was divided into homogeneous groups. In this study, the lower layers of the population were the tour guides of regional professional organizations. In addition, there are 13 tours guide professional associations in Turkey. The formula used to form a sample representing the entire population was: $\mathrm{n}=$ Number of Active Tour Guides under an Association/ Number of Active Tour Guides in Turkey. According to this formula, the data used in the research needed to be collected from 370 participants in $95 \%$ confidence interval and $p<, 05$ statistical significance level. The questionnaire forms were filled out through face-to-face, online platforms, and social media by 394 active tour guides working in various regions of Turkey. Three hundred seventy of the survey forms were included in the data analysis since some of them were eliminated because they were incomplete.

As of January 1, 2020, Ethics Committee Approval has become mandatory before data collection in Turkey. However, this article data was collected in 2016. Therefore, Ethics Committee Approval is not available, as such approval is not required when these data are collected.

\section{Analysis}

In this study, the data analysis was conducted with the IBM SPSS Statistics 22 program and Process Macro developed by Hayes (2013). In the initial analysis, mean, standard deviations, skewness, and kurtosis values were calculated. Then the factor loadings and Average Variance Extracted (AVE) values for indicators that reveal the constructs were analysed. Cronbach Alpha and Composite Reliability were also confirmed. Finally, correlation and discriminant validity were confirmed. Then, regression analysis based on the bootstrap method was conducted to test whether emotional exhaustion was mediated by the effect of economic anxiety on affective occupational commitment. The Bootstrap technique created a new observation set by repeating the observations in the original data set and making statistical calculations with the new data sets. This method corrected kurtosis and skewness related to the range, obtaining more reliable results (Gürbüz, 2019).

\section{Results}

\section{Initial analysis}

Two hundred forty-three men (65.7\%) and 127 (34.3\%) women participated in the study. 19 (5.1\%) of the participants were in the age range of 20-25 years; 88 (23.8\%) were in the age range of 26-31 years; 83 $(22.4 \%)$ were in the age range of 32-37 years; 68 (18.4\%) of them were in the age range of 38-43 years; 60 $(16.2 \%)$ of them were in the age range of $44-49$ years; $52(14.1 \%)$ were aged 50 years or above (See Table 1). It was observed that the skewness ( $\mathrm{S}$ ranged -1.02 to 1.00 ) and kurtosis ( $\mathrm{K}$ ranged from -0.37 to 1.63), coefficients of the variables ranged within \pm 2 normality criteria as set by George and Mallery (2010).

The means, standard deviations, skewness, and kurtosis are presented in Table 1 . When Table 1 was analysed, it was observed that the skewness (S ranged -1.02 to 1.00) and kurtosis (K ranged -0.37 to 1.63) coefficients of the variables were ranged within \pm 2 normality criteria as indicated by George and Mallery (2010). As seen in Table 2, the standardized estimates extend from 0.683 to 0.857 for economic anxiety, from 0.560 to 0.799 for affective occupational commitment, and from 0.615 to 0.801 for emotional exhaustion. It was found that all factor loads were significant. Average Variance Extracted (AVE) values were calculated to support convergent validity (Henseler, Ringle and Sinkovics, 2009). It was observed that the majority of variables in this study had AVE values over.50, and affective occupational commitment was slightly lower than .50. The cut-off value for Cronbach's alpha and Composite Reliability were 0.7 (Fornell and Larcker 1981; Nunnally 1978). When Table 2 is examined, it is also seen that CRs are considerably higher, and all variables were found to be reliable. 
Table 1: Demographic Characteristics of The Participants

\begin{tabular}{llcc}
\hline Variables & & $\mathbf{n}$ & $\%$ \\
\hline \multirow{2}{*}{ Gender } & Female & 127 & 34,3 \\
& Male & 243 & 65,7 \\
\hline \multirow{4}{*}{ Age } & $20-25$ & 19 & 5,1 \\
& $26-31$ & 88 & 23,8 \\
& $32-37$ & 83 & 22,4 \\
& $38-43$ & 68 & 18,4 \\
& $44-49$ & 60 & 16,2 \\
\multirow{5}{*}{ Seniority } & $50+$ & 52 & 14,1 \\
& 1 year and less & 34 & 9,2 \\
& 2-7 year & 103 & 27,8 \\
& 8-13 year & 103 & 27,8 \\
& $14-19$ year & 50 & 13,5 \\
& 20-25 year & 33 & 8,9 \\
& 26 + year & 47 & 12,7 \\
\hline
\end{tabular}

Table 2: Factor Loadings

\begin{tabular}{|c|c|c|c|c|}
\hline Scale Items & AVE & Cronbach a & CR & FL \\
\hline Economic Anxiety & .593 & .88 & .91 & \\
\hline $\begin{array}{l}\text { Because of the fear of failing to have a financially stable } \\
\text { and normal life with my income }\end{array}$ & & & & .805 \\
\hline $\begin{array}{l}\text { Because of the fear of failing to satisfy the needs of my family with my } \\
\text { income }\end{array}$ & & & & .846 \\
\hline Because of the fear of increasing social disrespect towards my job & & & & .686 \\
\hline $\begin{array}{l}\text { Because of the fear of failing to find career-related opportunities for self- } \\
\text { improvement }\end{array}$ & & & & .683 \\
\hline Financial conditions are not suitable for me to practice my occupation & & & & .857 \\
\hline $\begin{array}{l}\text { Because of the fear of limiting my social and cultural activities due to } \\
\text { financial problems and insufficient income levels }\end{array}$ & & & & .856 \\
\hline Because of the fear of losing my job due to social and political upheavals & & & & .618 \\
\hline Affective Occupational Commitment & .474 & .79 & .86 & \\
\hline Tour guiding profession is significant in terms of my personal image. & & & & .591 \\
\hline *I regret to have pursued a career in tour guiding. & & & & .742 \\
\hline${ }^{*} \mathrm{I}^{\prime} \mathrm{d}$ rather pursue a career in a profession other than tour guiding. & & & & .699 \\
\hline I am proud of being a tour guide. & & & & .799 \\
\hline *I don't like being a tour guide. & & & & .610 \\
\hline *I cannot identify myself with the occupation of tour guiding. & & & & .560 \\
\hline I consider tour guiding as an exciting profession. & & & & .697 \\
\hline Emotional Exhaustion & .522 & .87 & .90 & \\
\hline I feel like I don't like my job anymore & & & & .671 \\
\hline I feel emotionally drained when I come back home from work & & & & .798 \\
\hline I feel like I can't take this job anymore when I wake up every morning. & & & & .794 \\
\hline Dealing with people all day is wearing me out & & & & .719 \\
\hline I feel like I am sick of what I do for a living & & & & .801 \\
\hline I think my job is restricting me. & & & & .664 \\
\hline Working directly with people stresses me out & & & & .691 \\
\hline
\end{tabular}

The discriminant validity, which was the first introduced by Campbell and Fiske (1959) to evaluate test validity, proves that different scales in a test designed to measure theoretically different concepts do not correlate. Discriminant validity is approved if the square root of the AVE value of every construct becomes more significant than its correlation coefficient (Fornell and Larcker 1981). Although there is no standard value for discriminant validity, values below 0.85 suggest that discriminant validity likely exists between the two scales. The degree of fit in the two scales can be calculated with the following formula. In the formula, $r_{x y}$ shows the correlation between two different variables, $r_{x x}$ is the reliability of $\mathrm{X}, \mathrm{r}_{\mathrm{yy}}$ is the reliability of $\mathrm{y}$. For example, in the formula, if $\mathrm{x}$ is Economic Anxiety and $\mathrm{y}$ is Affective Occupational Commitment, discriminant validity is 0.219; In the case when $\mathrm{x}$ is Economic Anxiety, and $\mathrm{y}$ is Emotional Exhaustion, discriminant validity is 0.519; In the case when $\mathrm{x}$ is Affective Occupational Commitment, and y is Emotional Exhaustion, discriminant validity is 0.480 . 
$\frac{r_{x y}}{\sqrt{r_{x x} * r_{y y}}}$

Table 3: Discriminant Validity

\begin{tabular}{llllll}
\hline Variables & 1 & 2 & 3 & Mean & SD \\
\hline Economic Anxiety (EA) & .77 & & & 3.71 & .99 \\
Affective Occupational Commitment (AOC) & $-.16^{* *}$ & .69 & & 4.04 & .81 \\
Emotional Exhaustion (EE) & $.32^{* *}$ & $-.53^{* *}$ & -.10 & 2.39 & .95 \\
\hline
\end{tabular}

Note. ${ }^{* *} p<.01$, Diagonals (in bold) represents the square root of AVE while off diagonals represent correlations

In line with this, our model confirmed discriminant validity because the entire square root of AVEs was larger than the corresponding row or column entries (See Table 3). Details about correlations and discriminant validity are presented in Table 3. Economic anxiety was positively and significantly correlated with emotional exhaustion $(\mathrm{r}=.32, \mathrm{p}<.01)$. On the other hand, economic anxiety and emotional exhaustion were negatively and significantly correlated with affective occupational commitment $(\mathrm{r}=-.16$ and -.53). Emotional exhaustion negatively affects affective occupational commitment. Thus, $\mathrm{H}_{1}$ and $\mathrm{H}_{2}$ and $\mathrm{H}_{3}$ hypotheses were accepted.

The mediating role of emotional exhaustion in the effect of economic anxiety on affective occupational commitment was calculated via a Bootstrapping procedure. The experience as an active tour guide was used as a control variable, and direct and indirect effects were calculated. In the model, when the direct effects were examined (see Table 4), economic anxiety significantly and positively predicted emotional exhaustion $(\mathrm{B}=0.305, \mathrm{t}=6.401, \mathrm{p}<.001)$. Moreover, affective occupational commitment was significantly and negatively predicted by emotional exhaustion $(B=-0.366, t=-6.884, p<.001)$. After controlling mediational variables, Bootstrap analysis confirmed the direct effect of economic anxiety on affective occupational commitment $(B=-0.032, t=-0.861, p>0.05)$. Thus, the $\mathrm{H}_{4}$ hypothesis was accepted. Figure 1 shows the findings of the mediational analysis. Emotional exhaustion reduces affective occupational commitment levels, and emotional exhaustion has a partial mediating role between economic anxiety and affective occupational commitment. The analysis showed a weak negative correlation between economic anxiety and affective occupational commitment level.

Table 4: Mediational Analysis

\begin{tabular}{lllll}
\hline Variable & $B$ & SE & $t$ & $p$ \\
\hline Direct effect and total effect & & & & \\
a Economic anxiety $\rightarrow$ Emotional exhaustion & .305 & .048 & 6.401 & .001 \\
$b_{1}$ Emotional exhaustion $\rightarrow$ Affective commitment & -.366 & .053 & -6.884 & .001 \\
c Economic anxiety $\rightarrow$ Affective commitment & -.130 & .042 & -3.073 & .002 \\
$c^{\prime}$ Economic anxiety $\rightarrow$ Affective commitment & -.032 & .037 & -.861 & .340 \\
\hline Variable & Value & SE & LL 95\% CI & UL 95\% CI \\
\hline Bootstrap results for the indirect effect & & & & \\
EA $\rightarrow$ Emotional exhaustion $\rightarrow$ Affective commitment & -.112 & .023 & -.164 & -.073 \\
\hline
\end{tabular}

Note. Bootstrap sample size = 5000; LL lower Limit; UL Upper Limit; CI Confidence Interval. 


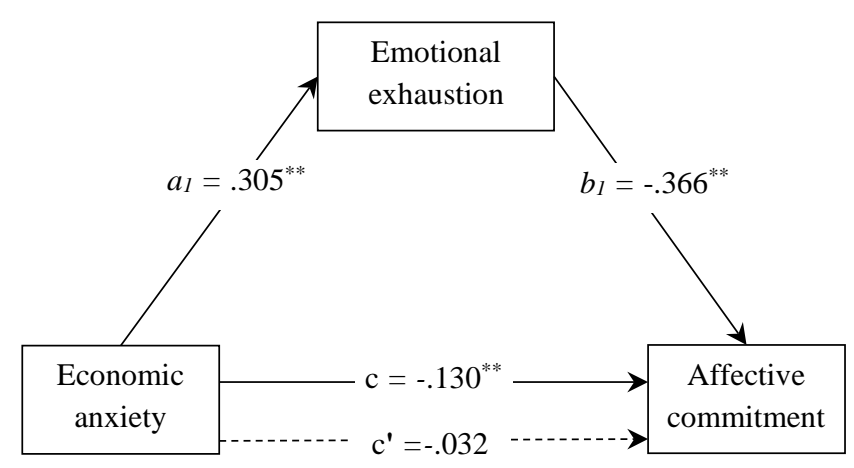

Figure 1. Structural Model

\section{Discussion and conclusions}

This study aimed to examine whether emotional exhaustion had a mediating effect on tour guides. Affective occupational commitment is considered among the most substantial types of commitment (Meyer et al. 1993). Thus, it was assumed in the design of this research that affective occupational commitment would not be strongly affected by economic anxiety. However, the analysis showed a weak negative correlation between economic anxiety and affective occupational commitment level. Economic anxiety is the most frequently observed in economic crises (Osberg, 2015; Karagüven, 2009; Hobfoll, 1989). Therefore, it is highly likely that the problems that impacted the Turkish tourism industry in this study may have influenced the economic perceptions of participant tour guides. These problems might have resulted from global and national fluctuations. Together with globalization, the crises not only affect where they prevail, but they may also affect the entire world as well, and this would harm tourism, which is a global industry ((Yetgin and Benligiray, 2019; Kaya, Akgün and Çiftçi, 2020). The Turkish tourism industry has been going through more challenging times with the Syrian refugee crisis, terrorism, the November 24, 2015 crisis with Russia, and the attempted July 15, 2016. The data of this study were implemented to tour guides in a political crisis environment in 2016. According to the Turkish Statistical Institute data, the number of tourists visiting Turkey decreased $24.6 \%$ in 2016 compared to the previous year but increased between 2017 and 2019. In line with the decreasing number of visitors, the overall tourism revenue has decreased drastically. The tourism revenue, which was $\$ 31.5$ billion in 2016, has decreased to $\$ 22$ billion in 2016. However, 2017, 2018, and 2019 may be considered a significant and bright era for Turkish tourism.

Due to the 'Novel Coronavirus (COVID-19)' pandemic, which first began in December 2019 and rapidly spread throughout the world, the COVID 19 pandemic was announced by the World Health Organization on March 11, 2020. The pandemic caused an economic crisis and increased the unemployment rates in Turkey and worldwide (Elgin, Başbuğ and Yalaman, 2020). Just like tour operators, travel agencies, and the employees of hotel and transportation businesses, one of the most significant actors of the sector, the tour guides, have also become unemployed, especially in times of crisis (Çakmak, 2019: 70; Yetgin, Yılmaz and Çiftçi, 2018). The tour guides could not work throughout the COVID-19 pandemic, and they faced severe economic problems. Thus, being one of the most intellectually qualified occupational groups in the tourism industry, if the tour guides quit their jobs and look for other sources of income due to economic problems, this may bring irreversible losses for the post-pandemic period. Therefore, the tour guides must be financially supported (Türker and Karaca, 2020). The tour guides expect financial support from the government in times of crisis (Şahin and Güzel, 2020; Kaya, Akgün and Çiftçi, 2020)

In addition to causing individuals to feel worthless, insignificant and unsuccessful economic crises also make them feel hopeless for the future. An individual who directly experiences economic crises in his/her business life would also reflect this around his/her family and friends. Thus, this may also damage their social lives (Avcin, Kucina, Sarotar, Radovanovic and Plesnicar, 2011). In an economic crisis, employees question their lifestyles, think they will lose their existing living standards, and have concerns about their future (Sargent-Cox Butterworth and Anstey, 2011). While Maslow suggests in his Hierarchy of Needs that people need to make financial gains to meet their physiological and safety needs (Maslow, 1943), Herzberg emphasises the importance of economic factors in motivation. It is suggested that success would never come, and even motivation would be lost unless these needs are satisfied (Herzberg, 1971). 
One of the most significant findings of this study is that the emotional exhaustion levels of tour guides grow with their economic anxiety levels. The risk of future unemployment increases anxiety for individuals who feel financially insecure (Luechinger et al., 2010). Low levels of income, insufficient wages, not having a regular income, unemployment, and economic crises are the factors that lead to economic anxiety (Osberg, 2015; Osberg and Sharpe, 2005). Individuals' living standards and levels of welfare would increase with the increase in their income levels (Frey and Stutzer, 2002). Otherwise, people would feel unhappy and experience economic anxiety. Economic anxiety impacts individuals' physical and mental well-being because of financial decline (Osberg and Sharpe, 2005). Similar results were found in this study, which suggested a significant relationship between economic anxiety and exhaustion and other studies which examined the relationship between income and exhaustion. For example, several studies found that teachers who are not happy with their wages experience more exhaustion (Otacioğlu, 2008). Likewise, part-time hotel employees are also underpaid, and since they work on a seasonal basis, their emotional exhaustion levels are higher (Ersoy and Utku, 2005). In addition, the individuals having financial difficulties usually tend to have side jobs, which causes emotional exhaustion and the increasing workload (Maslach and Leiter, 1997).

The concepts of occupational commitment and burnout have a strong relationship, but they hurt each other. Emotional exhaustion is the central aspect of burnout, and affective occupational commitment is occupational commitment (Meyer et al. 1993, Blau, 2000). It was found in this study that emotional exhaustion also reduced affective occupational commitment. It shows similarities with the results of other studies on occupational commitment and emotional exhaustion (Tümkaya and Uştu, 2016; Çiftçioğlu, 2011), In some other studies conducted with teachers and voluntary coaches, it was determined that affective occupational commitment negatively influences emotional exhaustion (Engelberg-Moston et al. 2009).

The tested model in this research revealed that emotional exhaustion reduces affective occupational commitment levels, and emotional exhaustion has a partial mediating role between economic anxiety and affective occupational commitment. With this result, which is one of the contributions of this study to the literature, it could be concluded that economic anxiety experienced by tour guides can indirectly reduce their affective occupational commitment by increasing their direct and emotional exhaustion levels. Furthermore, the analysis results showed that there is a weak and negative relationship between the economic anxiety levels of tour guides and their emotional, professional commitment; as the economic anxiety levels of tour guides increase, their emotional exhaustion levels increase; an increase in emotional burnout causes a decrease in the level of emotional, professional commitment of tour guides; emotional exhaustion partially mediates between economic anxiety and emotional, occupational commitment.

A committed individual is thought to stay in his/her work, with commitment protecting himself/herself against the adverse effects of stress by attributing meaning to their work (Kobasa 1982). If emotional exhaustion is considered a significant stress factor for individuals, it could be claimed that affective occupational commitment is one of the most important and protective variables for stress resistance. People with a salient identity toward a referent can develop coping strategies that assist them in the challenges created by their occupation. The results of another study revealed that the correlation between negative cases and burnout was more robust for the nurses who reported higher occupational commitment (Sawhney et al., 2020).

If the affective commitment of tour guides to their occupation increases, their professional performance will also increase. This would also lead to increased service quality in tours, and thus, increased tourist satisfaction. According to Lugosi and Bray (2008), social learning and experimental learning are essential for professional development. Therefore, education has a critical role in the development of practical occupational commitment. From this viewpoint, tour guides could be suggested to participate in specialization programs. On the other hand, a higher level of job satisfaction is a significant factor for increasing affective commitment (Kaldenberg et al., 1995; Tak and Çiftçioğlu 2008). Therefore, a fair income system for tour guides can solve various occupational problems (Mak, Wong, K. and Chang, 2011) and increase job satisfaction.

Individuals experiencing economic anxiety have concerns because they cannot guarantee their future. In addition, increasing levels of economic anxiety reduce affective occupational commitment levels. Thus, the economic anxiety of tourist guides should be reduced. In particular, being employed as tour guides in a permanent job can reduce economic anxiety. For this purpose, tour guides could specialize in different areas, and thus, they can be preferred more by travel agencies (Cohen, Ifergan and Cohen 2002). 
In the tour guiding literature, there are primarily studies focusing on the following topics: Duties, responsibilities, and roles of guides (Howard, Smith and Thwaites, 2001; Cohen et al. 2002; Tsaur and Teng, 2017), and occupational and professional problems (Büyüktepe, Gökdemir and Korkmaz, 2019; Mak, Wong and Chang, 2011; Prakash and Chowdhary, 2011; Chowdhary and Prakash, 2008; Batman, 2003, Polat, 2001). Therefore, this study is expected to raise awareness in tour guides, attract those who employ tour guides, and fill an important gap in the related literature. Furthermore, it can be said that it contributes to the academic fields of economic anxiety, affective occupational commitment, and emotional exhaustion.

Travel agencies usually make comprehensive tour plans, and they plan the destination and excursions. However, it is known that tour guides are not involved in the tour planning processes. This situation brings about some administrative problems as well as causing tour guides to experience difficult moments during tours (Pond, 1993). This can lead to a decrease in the practical occupational commitment of tour guides, coupled with economic anxiety and burnout. Within this context, guides can also be included in the planning of the tours. Practices that involve employees in decision-making processes and allowing them personal growth (i.e., competence) help support employees' organizational affective commitment (Morrow, 2011). Ensuring that the guides participate in this process will mean that they will have partial control over the process. As a result, it may be possible to prevent role conflicts and reduce emotional exhaustion levels. This is critical for a successful tour operation.

Tourism is a developing sector in our country. Recent crises (such as the Syrian refugee crisis, terrorism, the November 24, 2015 crisis with Russia, and the attempted coup of July 15, 2016) in the tourism industry have caused approximately 250.000 people to become unemployed in this sector. Tour guides were among these unemployed tourism employees. Thus, the decline in the number of tourists and work chances for tourist guides may have caused an increase in their economic anxieties experienced for various reasons. Besides, macroeconomic conditions are only one of the reasons for economic anxiety. Tour guides are effective cultural ambassadors in promoting their countries. In such severe crises, professional chambers and employee associations undertake essential tasks. To provide financial support to tour guides, meeting with the relevant associations should be organised to minimize the economic anxieties of tour guides (such as interest-free loans, debt or loan assistance), and outcomes of such efforts should be shared with tour guides.

Tour guides with higher affective occupational commitment may strive to improve their professionrelated problems. Participation is an essential factor in the development of commitment. Therefore, the associations of tour guides should get the guides' opinions, take the necessary steps to solve their problems in the right way and inform guides about the taken steps.

\section{Limitations and future research}

This study was conducted on tour guides actively working, and inactive tour guides who had licenses were excluded from the sample. As of 2016, there is 2707 inactive tour guide in Turkey. In such a study conducted on tour guides, inactive tour guides were excluded from the sample, considering it would be difficult to reach them. Therefore, their opinions were not reflected in this research. Another limitation is that this study used only the questionnaire method as the data collection technique. In addition, the fact that the questionnaire could not be administered to all tour guides through face-toface interviews since they operate throughout the country can be considered another limitation.

Tour guiding is a profession that is practised in a similar way all over the world. However, the economic and cultural conditions in the region may cause tour guides to differentiate in the level of affective occupational commitment and other variables (such as emotional labour, work stress, emotional intelligence) that affect this commitment. Therefore, it can be suggested that similar studies could be conducted in different cultures, and the findings could be compared.

This is a cross-sectional study. When developing a general hypothesis, cross-sectional studies are the best way to establish specific situations facing a particular demographic. Each description of critical data points creates the possibility of communicating movement towards a future solution that may not have been considered before. In cross-sectional studies, data are collected from many subjects at a single point. Whereas variables occur in real-time situations, what happens now can have different consequences from what may happen in the future. Therefore, it can never be said that the sample ultimately represents the whole universe. Therefore, it is not possible to make a complete generalization when using this approach. Furthermore, a cross-sectional study only measures the presence and relationships in that environment, not what triggers the variables. Therefore, it does not provide causal relationships (Wang and Cheng, 2020; Sedgwick, 2014; Levin, 2010). 
Economic anxiety, affective occupational commitment, and emotional exhaustion levels of tour guides may change depending on various factors. For example, the rapid spread of coronavirus (COVID-19) globally has negatively affected many sectors, including tourism, since the beginning of 2020. Especially the fact that international tourism has come to a standstill has affected tour guides significantly. In our opinion, testing and comparing the relationship between economic anxiety, affective commitment, and emotional exhaustion in different regions and cultures have become even more critical in this process. In addition, it has also become vital to study and analyse many other effects of the pandemic in an interdisciplinary manner. It can also be suggested that further studies could be conducted with both active and inactive tour guides, enriching the collected data with qualitative methods, conducting longitudinal research and comparing the obtained findings in different periods.

\section{Peer-review:}

Externally peer-reviewed

\section{Conflict of interests:}

The author(s) has (have) no conflict of interest to declare.

\section{Grant Support:}

The authors declared that this study has received no financial support

\section{Author Contributions:}

Idea/Concept/Design: S.B., D.Y. Data Collection and/or Processing: D.Y. Analysis and/or Interpretation: D.Y., S.B. Literature Review: D.Y., S.B. Writing the Article: S.B., D.Y. Critical Review: S.B. Approval: S.B., D.Y.

\section{References}

Abdelkader, A. (2016). Tourist guides and job-related problems, analysis and evidence from Jordan Journal of Quality Assurance in Hospitality and Tourism, 18 (2), 200-217.

Adams, G.A., and Webster, J.R. (2013). "Emotional regulation as a mediator between interpersonal mistreatment and distress". Eur. J. Work Organ. Psychol. 22(6), 697-710.

Ağırman, Ü. H., and Naktiyok, A. (2014). Hizmet sektörü çalışanlarından beklenen duygu gösterimlerinin mesleki bağlllık ve duygusal tükenmişlik düzeylerine etkisi: hemşireler üzerine bir araştırma. 2. Örgütsel Davranış Kongresi Proceeding Book pp.7-8.

Anastasiou, S. (2020). Economic Crisis, Emotional Exhaustion, Depersonalization and Personal Accomplishment Of Teachers in Greece. Humanities and Social Sciences Letters, 8(2), 230-239.

Ap, J., and Wong, K. K. F. (2001). Case study on tour guiding: Professionalism, issues and problems. Tourism Management, 22(5), 551-563.

Aranya, N. and Jacobson, D. (1975). An empirical study of theories of organizational and occupational commitment. The Journal of Social Psychology, 97 (1), 15-22.

Arslantürk, Y. (2016). Mesleki bağlllık: Turist rehberleri üzerine bir inceleme. İşletme Araştırmaları Dergisi, 81, 186-207.

Avcin, B.A., Kucina, A.U., Sarotar, B.N., Radovanovic, M. and Plesnicar, B. K. (2011). The present global financial and economic crisis poses an additional risk factor for mental health problems on the employees. Psychiatr Danubina, 23 (1), 142-148.

Bagraim, J. (2003). The dimensionality of professional commitment. Journal of Industrial Psychology, 29(2), 6-9.

Bareket-Bojmel, L., Shahar, G., and Margalit, M. (2020). COVID-19-related economic anxiety is as high as health anxiety: Findings from the USA, the UK, and Israel. International Journal of Cognitive Therapy, $29,1-9$. 
Batman, O. (2003). Türkiye'deki profesyonel turist rehberlerinin mesleki sorunlarına yönelik bir araştırma. Bilgi Sosyal Bilimler Dergisi, (2), 117-134.

Bell, D. N. F., and Blanchflower, D. G. (2011). The crisis, policy reactions and attitudes to globalization and jobs. In M. Bacchetta and M. Jansen (Eds.), Making globalization socially sustainable (pp. 85118). Geneva: ILO and WTO.

Benligiray, S., and Sönmez, H. (2013). The analysis of demographic and work-life variables which affect the occupational commitment of nurses. Journal of Management Development, 32 (4), 419-434.

Blau, G. (1989). Testing the generalizability of a career commitment measure and its impact on employee turnover. Journal of Vocational Behavior, 35 (1), 88-103.

Blau, G. (2000). Job, organizational, ve professional context antecedents as predictors of intent for interrole work transitions. Journal of Vocational Behavior, 56, 330-345.

Blau, G. (2003). Testing for a four-dimensional structure of occupational commitment Journal of Occupational and Organizational Psychology, 76, 469-488.

Brown, A. L. and Roloff, M. E. (2011). Extra-role time, burnout, and commitment: The power of promises kept. Business Communication Quarterly. 74 (4), 450-474.

Burke, R. J., Greenglass, E. R. and Schwarzer, R. (1996). Predicting teacher burnout over time: effects of work stress, social support, and self-doubts on burnout and its consequences. Anxiety, Stress, and Coping, 9, 261-275.

Büyüktepe, H. S., Gökdemir, S., and Korkmaz, H. (2019). Turist Rehberlerinin Sorunları Üzerine Nitel Bir Araştırma: Çanakkale Örneği. Journal of Travel and Tourism Research, (14), 94-117.

Cabi, E. and Yalçınalp, S. (2013). Öğretmen adaylarına yönelik mesleki kaygı ölçeği (MKÖ): Geçerlik ve Güvenirlik Çalışması. Hacettepe Üniversitesi Eğitim Fakültesi Dergisi, 44, 85-96.

Çakmak, T. F. (2019). Turizm Endüstrisinde Bütüncül Yaklaşımla Kriz Yönetimi ve Örnek Olaylar. Ankara: Detay Yayıncilik

Campbell, D.T. and Fiske, D.W. (1959). Convergent and discriminant validation by the multitraitmultimethod matrix. Psychological Bulletin, 56, 81-105.

Çapri, B. (2006). Tükenmişlik ölçeğinin Türkçe uyarlaması: Geçerlik ve güvenirlik çalışması. Mersin Üniversitesi Eğitim Fakültesi Dergisi, 2(1), 62-77.

Casselman, B. (2017). Stop saying Trump's win had nothing to do with economics. FiveThirtyEight. Retrieved from https://fivethirtyeight.com/features/stop-saying-trumps-win-hadnothing-to-dowith-economics/

Çelebi, E., (2013). Elazı ̆̆ ve Malatya il merkezinde bulunan özel eğitim kurumlarında çalışan öğretmenlerin tükenmişlik düzeyleri ve ilgili faktörler (Unpublished doctoral dissertation). Fırat University, Elazı̆̆.

Chang, H. T., Chi, N. W. and Miao, M. C. (2007). Testing the relationship between three-component organizational/occupational commitment and organizational/occupational turnover intention using a non-recursive model, Journal of Vocational Behavior, 70, 352-368.

Choi, C. H. Kim, T. Lee, G. and Lee, S. K. (2014). Testing the stressor-strain-outcome model of customer-related social stressors in predicting emotional exhaustion, customer orientation and service recovery performance. International Journal of Hospitality Management, 36, 272-285.

Chowdhary, N. and Prakash, M. (2008). Challenges of tour guiding - An assessment of situation in India. Gwalior, India: Indian Institute of Tourism and Travel Management.

Chu, K.H.-L. and Murrmann, S.K. (2006). Development and validation of the hospitality emotional labor scale. Tourism Management. 27 (6), 1181-1191.

Çiftçioğlu, A. (2011). Investigating occupational commitment and turnover intention relationship with burnout syndrome. Business and Economics Research Journal, 2 (3), 109-119.

Cohen, A. (2007). Dynamics between occupational and organizational commitment in the context of flexible labor markets: A review of the literature and suggestions for a future research agenda. Inst. Technik und Bildung. 
Cohen, E. H., Ifergan, M. and Cohen, E. (2002). A new paradigm in guiding the madrich as a role model. Annals of Tourism Research, 29 (4), 919-932.

Conner, D. N. (2006). Occupational commitment, education, and experience as a predictor of intent to leave the nursing profession. Nursing Economic, 24(2), 86-93.

Cotton, D.H.G. (1990). Stress Management, USA: Brunner-Routledge.

Cunningham, P. H., Tang, T. L. P., Frauman, E., Ivy, M. I. and Perry, T. L. (2012). Leisure ethic, money ethic, and occupational commitment among recreation and park professionals: Does gender make a difference? Public Personnel Management, 41 (3), 421-448.

Dă̆, I. (1999). Psikolojinin ışığında kaygı. Doğu Batı Düşünce Dergisi. 6, 181-189.

Davenport, N., Schwartz, R. D., and Elliott, G. P. (2003). Mobbing: Emotional abuse in the American workplace (Mobbing; İsyerinde Duygusal Taciz. Translated by O.Önertoy). İstanbul: SistemYayıncllık.

Deery, S., Iverson, R., and Walsh, J. (2002). Work relationships in telephone call centres: Understanding emotional exhaustion and employee withdrawal. Journal of Management Studies, 39 (4), 471-496.

Ditfurth, H. (1991). Korku ve Kaygı. (Translation: Nasuh Barın). (First Edition). İstanbul: Metis Publishing.

Elgin, C., Basbug, G., and Yalaman, A. (2020). Economic policy responses to a pandemic: Developing the COVID-19 economic stimulus index. Covid Economics, 1(3), 40-53.

Engelberg-Moston, T., Stipis, C., Kippin B., Spillman S. and Burbidge K. (2009). Organisational and occupational commitment as predictors of volunteer coaches' burnout. Australian Journal on Volunteering, 14 (1), 1-9.

Fawzy, F.I., Fawzy, N.W., and Pasnau (1991). Burnout in the health professionals, Handbook of Studies on General Hospital Psychiatry, Elsevier Science Publishers BV, Amsterdam, 119.

Finbow, R. G. (2018). Can transatlantic trade relations be institutionalised after Trump? Prospects for EU-US trade governance in the era of antiglobalist populism. In Institutionalisation beyond the nation state: Transatlantic relations: Data, privacy and trade law (pp. 187-211). Cham: Springer International Publishing.

Fırat, M. Z. (2015). Tükenmişlik ve örgütsel bağhllı̆̆ın mesleki bağlllı üzerindeki etkileri: banka çalışanlar üzerinde bir araştırma. (Unpublished P.Hd). İstanbul: Haliç Üniversitesi.

Fornell, C. and Larcker, F. D. (1981). Evaluating structural equation models with unobservable variables and measurement error. Journal of Marketing Research, 18 (1), 39-50.

Freud, S. (1984). Psikanalize Giriş. (Third Edition, Translation: Günsel Koptagel-İlal), İstanbul: Altın Kitaplar Publishing.

Frey, B. S., and Stutzer, A. (2002). What can economists learn from happiness research? Journal of Economic Literature, 40 (2) .402-435.

Friedman, H. S. and Schustack, M. W. (1999). Personality: Classic theories and modern research. Boston, MA: Allyn and Bacon.

Garman, A. N., Corrigan, P. and Morris, S. B., (2012). Staff Burnout and Patient Satisfaction: Evidence of Relationships at the Care Unit Level. Journal of Occupational Health Psychology, 7(3), 235-41.

Geçtan, E. (2005). Psikanaliz ve Sonrası. (11th Edition). İstanbul: Metis Publishing.

George, D. and Mallery, M. (2010). SPSS for Windows Step by Step: A Simple Guide and Reference, 17.0 Update, 10th Edition, Boston: Pearson.

Goldberg, L.S. and Grandey, A.A. (2007). Display rules versus display autonomy: emotion regulation, emotional exhaustion, and task performance in a call center simulation. J. Occup. Health Psychol. 12(39), 301-318.

Goulet, R.and Singh, P. (2002). Career commitment: A reexamination and an extension. Journal of Vocational Behavior, 6, 73-91.

Greenhaus, J. H. (1971). An investigation of the role of career salience in vocational behavior. Journal of Vocational Behavior, 1 (3), 209-216. 
Griffin, J. M, Fuhrer, R., Stansfeld, S. A. and Marmot, M. (2002). The importance of low control at work and home on depression and anxiety: do these effects vary by gender and social class?. Soc Sci Med, 54(5), 783-98.

Güleryüz, G., Güney, S., Aydın, E.M. and Aşan, Ö. (2008). The mediating effect of job satisfaction between emotional intelligence and organisational commitment of nurses: a questionnaire survey. International Journal of Nursing Studies. 45, 1625-1635.

Gürbüz, S. (2019). Sosyal bilimlerde aracı, düzenleyici ve etki analizleri. Ankara: Seçkin Publisihing

Han, S. J., Bonn, M. A., and Cho, M. (2016). The relationship between customer incivility, restaurant frontline service employee burnout and turnover intention. International Journal of Hospitality Management, 52, 97-106.

Hayes, A.F. (2013). Introduction to mediation, moderation, and conditional process analysis: A regression-based approach. New York: Guildford Publication.

Henseler, J., Ringle; C.M. and Sinkovics, R.R. (2009). The use of partial least squares path modeling in international marketing. Advances in International Marketing, 20, 277-319.

Herzberg, F. (1971). The motivation-hygiene theory. Work and the nature of man, 4 . https://www.marketplace.org/topics/economy/anxiety-index (Accessed: 04.02.2019)

Howard, J., Smith, B. and Thwaites, R. (2001). Investigating the role of the Indigenous tour guide. Journal of Tourism Studies, 12 (2), 32.

Jackson, S. E.,Turner, J.A. and Brief, A. P., (1987). Correlates of burnout among public service lawyers. Journal of Occupational Behaviour, 8 (4), 339-349.

Jeffrey, C., Weatherholt, N. and Lo, S. (1996). Ethical development, professional commitment and rule observance attitudes: a study of auditors in Taiwan. The International Journal of Accounting, 31, 365379.

Kaldenberg, D. O., Becker, B. W. and Zvonkovic, A. (1995). Work and commitment among young professionals: A study of male and female dentists. Human Relations, 48 (1), 1355-1377.

Kaplan, S.E. and Whitecotton, S.M. (2001). An examination of auditors' reporting intentions when another auditor is offered client employment. Auditing A Journal of Practice and Theory, 20(1), 44-63.

Karagüven, H.Ü. (2009). Psychological impact of an economic crisis: a conservation of resources approach, International Journal of Stress Management, 16 (3), 177-194.

Kaya, A., Akgün Y.D., and Çiftçi, G. (2020). Krizlerin turist rehberliği öğrencilerinin mesleki tutumları ile ilişkisi. Türk Turizm Araştırmalan Dergisi, 4(3), 2907-2923.

Kierkegaard, S. (2004). Kaygı kavramı. Ankara: Hece Publication.

Kim, T. H. and Chang, K. R. (2007). Interactional effects of occupational commitment and organizational commitment of employees in sport organizations on turnover intentions and organizational citizenship behaviors. International Journal of Applied Sports Sciences, 19 (2), 63-79.

Kim, T.T., Yoo, J.J.-E., Lee, G., Kim, J., (2012). Emotional intelligence and emotional labour acting strategies among frontline hotel employees. International Journal of Contemporary Hospitality Management. 24 (7), 1029-1046.

Knudsen, H. K., Roman, P. M. and Abraham, A. J. (2013). Quality of clinical supervision and counsellor emotional exhaustion: The potential mediating roles of organizational and occupational commitment. Journal of Substance Abuse Treatment, 44(5), 528-533.

Kobasa, S.C. (1982). Commitment and coping in stress resistance among lawyers. Journal of Personality and Social Psychology, 42 (4), 707- 717.

Larson, J. H, Wilson, S. M. and Beley, R. (1994). The impact of job insecurity on marital and family relationships. Family Relations, 43 (2), 138-143.

László, K. D., Pikhart, H., Kopp, M. S., Bobak, M., Pajak, A., Malyutina, S. and Marmot, M. (2010). Job insecurity and health: A study of 16 European countries. Social Science and Medicine, 70(6), 867-874.

Lee, K., Carswell, J.J. and Allen, N.J. (2000) A Meta-Analytic review of occupational commitment: relations with person- and work-related variables. Journal of Applied Psychology, 85, 799-811. 
Lee, K., Carswell, J.J. and Allen, N.J. (2000). A meta-analytic review of occupational commitment: Relations with person ve work related variables. Journal of Applied Psychology, 85, 799-811.

Lee, R.L. and Ashforth, B. (1996). A meta-analytic examination of the correlates of the three dimensions of job burnout. Journal of Applied Psychology, 81(2), 123-33.

Leiter, M. P., and Maslach, C. (1988). The impact of interpersonal environment on burnout and organizational commitment. Journal of Organizational Behavior, 9, 297-308

Leiter, M.P. and Christina Maslach, C. (2003). Areas of Worklife: A Structured Approach to Organizational Predictors of Job Burnout. Research in Occupational Stress and Well Being, 3, 91-134.

Lerhman, K. (1986). When fact and fantasy collide: Crisis management in the travel industry. Public Relations Journal, 42 (2), 25-28.

Levin, K.A. (2010). Study design III: Cross-sectional studies. Evidence-Based Dentistry, 7, 24-25 (https://www.nature.com/articles/6400375.pdf)

Lin, C.P. (2007). To share or not to share: modelling tacit knowledge sharing, Its mediators and antecedents. Journal of Business Ethics, 70(4), 411-428.

Lingard, H. and Francis, V. (2005). The decline of the 'traditional' family: work-life benefits as a means of promoting a diverse workforce in the construction industry of Australia. Construction Management E Economics, 23, 1045-1057.

Liu, Lr., Li, C.J., Long, Y.F. and Zhan, C.L. (2009). Structure validity of an occupational commitment scale for traditional Chinese Medical Practitioners, 40 (2), 318-321.

Lozza, E., Libreri, C and Bosio A. C. (2012). Temporary employment, job insecurity and their extraorganizational outcomes. Economic and Industrial Democracy, 34: 89-105.

Luechinger, S., Meier S. and Stutzer, A. (2010). Why does unemployment hurt the employed? Evidence from the life satisfaction gap between the public and the private sector. Journal of Human Resources $45,998-1045$.

Lugosi, P. and Bray, J. (2008). Tour guiding, organisational culture and learning: Lessons from an entrepreneurial tour company. International Journal of Tourism Research, 10 (5), 467-479.

Mak, A. H. N., Wong, K. K. F. and Chang, R. C. Y. (2011). Critical issues affecting the service quality and professionalism of the tour guides in Hong Kong and Macau. Tourism Management, 32 (6), 14421452.

Maldonado, L. E., and Alicea, B. E. R. (2002). Vocational interest and vocational satisfaction of licensed psychologists in Puerto Rico. Interamerican Journal of Psychology, 36 (1-2), 191-213.

Mancini, M. (2001). Conducting Tours. (3rd Ed), New York: Delmar Publishers.

Marjanovic, Z., Greenglass, E. R., Fiksenbaum, L., and Bell, C. M. (2013). Psychometric evaluation of the financial threat scale (FTS) in the context of the great recession. Journal of Economic Psychology, 36, 110.

Markovits, Y., Boer, D. and Dick, R. (2014). Economic crisis and the employee: The effects of economic crisis on employee job satisfaction, commitment, and self-regulation. European Management Journal, $32,413-422$

Maslach, C. (2003). Job Burnout: New Directions in Research and Intervention. Current Directions in Psychological Science, 12(5), 189-192.

Maslach, C. and Jackson, S. E. (1981). The measurement of experienced burnout. Journal of Occupational Behaviour, 2, 99-113.

Maslach, C. and Leiter, M. (1999). Teacher burnout: A research agenda. In R. Vandenberg \& A. Huberman (Eds.), Understanding and Preventing Teacher Burnout (pp. 295-303). Cambridge: Cambridge University Press.

Maslach, C. and Leiter, M.P. (1997). The truth about burnout. San Francisco: Jossey Bass.

Maslach, C. ve Goldberg, J. (1998). Prevention of burnout: New perspectives. Applied and preventive psychology, 7(1), 63-74.

Maslach, C., Schaufeli, W. B. and Leiter, M. P. (2001). Job burnout, Annual Review of Psychology, 52 (1), 397-422. 
Maslow, A. H. (1943). A theory of human motivation. Psychological Review, 50, 370-396.

May, T. Y. M., Korczynski, M.and Frenkel, S. J. (2002). Organizational and occupational commitment: Knowledge workers in large corporations. Journal of Management Studies, 39 (6), 775-801.

McCarthy, J. M., Trougakos, J. P. and Cheng, B. H. (2016). Are anxious workers less productive workers? It depends on the quality of social exchange. Journal of Applied Psychology, 101(2), 279-291.

Meged, J. W. (2017). Guides crafting meaning in a flexible working life. Scandinavian Journal of Hospitality and Tourism, 17 (4), 374-387.

Meier, T. S. (1983). Toward a theory of burnout, Human Relations, 36 (10), 899-910.

Meltzer, H., Bebbington, P., Brugha, T., Jenkins, R., McManus, S. and Stansfeld, S. (2009). Job insecurity, socio-economic circumstances and depression. Psychological Medicine, 40 (8), 1401-1407.

Meyer, J. and Allen, N. (1997). Commitment in the workplace: Theory, research, and application., Thousand Oaks, CA: SAGE Publications.

Meyer, J. P. and Herscovitch, L. (2001). Commitment in the workplace: Toward a general model. Human Resource Management Review 11(3), 299-326.

Meyer, J. P., Stanley, D. J., Herscovitch, L.and Topolnytsky, L. (2002). Affective, continuance, and normative commitment to the organization: A meta-analysis of antecedents, correlates, and consequences. Journal of Vocational Behavior, 61(1), 20-52.

Meyer, J.P, Allen, N.J. ve Smith, C.A. (1993). Commitment to organizations and occupations: Extension and test of a three-component conceptualization. Journal of Applied Psychology, 78, 538-551.

Morrow, P.C. (2011). Managing organizational commitment: Insights from longitudinal research. Journal of Vocational Behavior, 79, 18-35.

Nunnally, J. C. (1978). Psychometric theory. (2. bask1.). New York: McGraw-Hill.

Osberg, L. (2009). Measuring economic security in insecure times: New perspectives, new events, and the index of economic well-being. CSLS Research Report.

Osberg, L. (2015). How should one measure economic insecurity? OECD Statistics Working Papers, 1, OECD Publishing.

Osberg, L. and Sharpe A. (2005). How should we measure the 'economic' aspects of well-being? Review of Income and Wealth, 51(2), 311-336.

Otacıoğlu, S. G. (2008). Müzik öğretmenlerinde tükenmişlik sendromu ve etkileyen faktörler. İnönü Üniversitesi Eğitim Fakültesi Dergisi, 9,103-116.

Otto K., Dette-Hagenmeyer D.E. and Dalbert C. (2010). Occupational mobility in members of the labor force: Explaining the willingness to change occupations. Journal of Career Development, 36, 262-288.

Özer, G. and Uyar, M. (2010). Muhasebecilerin etik oryantasyonlarının mesleki bağlllığa etkisi üzerine bir inceleme. Muhasebe ve Finansman Dergisi, 48, 89-100.

Pai, F.-Y., Yeh, T.-M. and Huang, K.-I (2012). Professional Commitment Of Information Technology Employees Under Depression Environments. International Journal of Electronic Business Management, 10 (1), 17-28.

Pines, A.M. (1996). Couple burnout. New York/London: Routledge.

Polat, T. (2001). Seyahat işletmelerinde profesyonel turist rehberliği, rehberlik mesleğinin sorunları ve çözüm önerileri üzerine bir alan araştırması. (Unpublished Master Thesis) Anadolu University.

Pond, K. L. (1993). The professional guide. New York: Van Nostrve Reinhold.

Prakash, M. and Chowdhary N. (2011). Tour guiding: Interpreting the challenges, Tourismos: An International Multidiciplinary Journal of Tourism, 6 (2), 65-81.

Rafaeli, A. Grandey, A.A., Ravid, S.and Wirtz, J. (2006). Culture, display rules and organization: the effects of globalization. In: Paper Presented at the Academy of Management, Atlanta, GA.

Raiziene, S. and Endriulaitiene A. (2007). The relations among empathy, occupational commitment, and emotional exhaustion of nurses. Medicana (Kaunas). 43 (5), 425-31 
Ritzer, G. and H. Trice. (1969). An Empirical Study of Howard Becker's Side-Bet Theory. Social Forces, 47 (2), 475-478.

Rook, K., Dooley, D. and Catalano, R. (1991). Stress transmission: The effects of husbands' job stressors on the emotional health of their wives. Journal of Marriage and the Family, 165-177.

Rothman, J. (1997). Resolving identity-based conflict in nations, organizations, and communities. San Francisco, CA: Jossey-Bass.

Şahin, İ., and Güzel, F. Ö. (2020). Olumsuz güncel gelişmelerin ve krizlerin türk turizmine etkileri: profesyonel turist rehberlerinin değerlendirmeleri ve sektörel çözüm önerileri. İstanbul Gelişim Üniversitesi Sosyal Bilimler Dergisi, 7(2), 257-280.

Sargent-Cox K, Butterworth P. and Anstey KJ. (2011). The global financial crisis and psychological health in a sample of Australian older adults: A longitudinal study. Soc Sci Med, 73, 1105-1112

Satoh, M., Watanabe, I. and Asakura, K. (2017). Factors related to affective occupational commitment among Japanese nurses. Open Journal of Nursing, 7, 449-462.

Sawhney G., Britt TW, Sinclair RR, Mohr CD, and Wilson CA (2020). Is commitment to one's profession always a good thing? Exploring the moderating role of occupational commitment in the association between work events and occupational health. Journal of Career Assessment, 3, 1-20.

Sedgwick, P. (2014). Cross sectional studies: advantages and disadvantages. BMJ (online), 348, g2276

Swim, J. K., Johnston, K. and Pearson, N. B. (2009). Daily experiences with heterosexism: Relations between heterosexist hassles and psychological well-being. Journal of Social and Clinical Psychology, 28 (5), 597-629.

Tak, B. and Çiftcioglu. A. (2009). Üç boyutlu mesleki bağlllık ölçeğinin Türkçe'de güvenilirlik ve geçerliliğin incelenmesine yönelik bir alan araştırması. Dokuz Eylül Üniversitesi İşletme Fakültesi Dergisi 10 (1), 35-54.

Tang, T. L. P., Cunningham, P. H., Frauman, E., Ivy, M. I. and Perry, T. L. (2012). Attitudes and occupational commitment among public personnel: Differences between baby boomers and GenXers. Public Personnel Management, 41(2), 327-360.

Toker, A. (2019). Gecekondu Turizminde Turist Rehberlerinin İlham Verici Rolü. Journal of Tourism and Gastronomy Studies, 7(4), 3029-3044

Tsai, H. A. (2007). Job characteristics, burnout and occupational commitment in the banking service context (Unpublished master's thesis). Tatung University, China.

Tsaur S. and Lin W. (2014). Hassles of tour leaders. Tourism Management, 45, 28-38.

Tsaur, S. H., and Teng, H. Y. (2017). Exploring tour guiding styles: The perspective of tour leader roles. Tourism Management, 59, 438-448.

Tümkaya, S. and Uştu, H. (2016). Tükenmişliğin mesleğe bağlllıkla ilişkisi: Sınıf öğretmenleri üzerine bir araştırma. Mersin Üniversitesi Eğitim Fakültesi Dergisi, 12 (1), 272-28.

Türker, A., and Karaca, K. Ç. (2020). Tourism and tourist guidance after a novel coronavirus (COVID19). Turist Rehberliği Nitel Araştırmalar Dergisi, 1(1), 1-19.

Verbeke, H. (1996). Individual differences in emotional contagion of salerspersons, Its Effecy on Performance and Burnout. Psyhology and Marketing, 14(6), 617- 636.

Visser, W. A. and Rothmann, S. (2009). The development of a hassle-based diagnostic scale for predicting burnout in call centres. SA Journal of Human Resource Management, 7 (1), 92-99.

Walker, D.D., van Jaarsveld, D.D. and Skarlicki, D.P. (2014). Exploring the effects of individual customer incivility encounters on employee incivility: The moderating roles of entity (in) civility and negative affectivity. J. Appl. Psychol, 99 (1), 151-161.

Wang, X. and Cheng, Z. (2020). Cross-Sectional Studies: Strengths, Weaknesses, and Recommendations. Chest, 158 (1), S65-S71.

Weiler, B. and Black, R. (2015). Tour Guiding Research, Insights, Issues and Implications, Channel View Publications, UK.

Weiten, W., Hammer E. Y. and Dunn, D.S. (2016). Psikoloji ve çă̆daş yaşam insan uyumu. (Çev. Ed.F. Ebru İkiz). Ankara: Nobel Akademik Publishing. 
Weng, Q. and McElroy, J. C. (2012), Organizational career growth, affective occupational commitment and turnover intentions, Journal of Vocational Behavior, 80, 256-265.

Whalen, C. J. (1997). Money-manager capitalism and the end of shared prosperity. Journal of Economic Issues, 31(2), 517-525.

Wong, J. Y. and Wang, C. H. (2009). Emotional labor of the tour leaders: An exploratory study. Tourism Management, 30, 249-259.

Wright, T. A. and Bonett, R. (1997). The contribution of burnout to work performance. Journal of Organizational Behavior, 18 (5), 491-499.

Yetgin, D. (2017). Turist rehberlerinin tükenmişlik ve ekonomik kaygı düzeylerinin mesleki bağlllık düzeyleri üzerindeki etkisi. (Unpublished P.Hd) Anadolu University.

Yetgin, D., and Benligiray, S. (2019). The effect of economic anxiety and occupational burnout levels of tour guides on their occupational commitment. Asia Pacific Journal of Tourism Research, 24(4), 333-347.

Yetgin, D., Yılmaz, A. and Çiftçi, G. (2018). Krizlerin turist rehberliği öğrencilerinin kariyer planlamasındaki etkisi. Journal of Tourism and Gastronomy Studies,6 (3), 195, 214. 